\title{
Differential susceptibility in steelhead trout populations to an emergent MD strain of infectious hematopoietic necrosis virus
}

\author{
Rachel Breyta ${ }^{1,2, *}$, Amelia Jones ${ }^{1}$, Gael Kurath ${ }^{1,2}$ \\ ${ }^{1}$ US Geological Survey, Western Fisheries Research Center, 6505 NE 65th St., Seattle, WA 98115 \\ ${ }^{2}$ School of Aquatic and Fishery Sciences, University of Washington, Seattle, WA 98195
}

\begin{abstract}
A significant emergence of trout-adapted MD subgroup infectious hematopoietic necrosis virus (IHNV) began in the coastal region of Washington State, USA, in 2007. This emergence event lasted until 2011 and caused both asymptomatic adult fish infection and symptomatic epidemic disease and mortality in juvenile fish. Incidence of virus during this emergence demonstrated a heterogeneous distribution among rivers of the coastal region, leaving fish populations of some rivers apparently untouched while others suffered significant and recurrent infection and mortality (Breyta et. al. 2013; Dis Aquat Org 104:179-195). In this study, we examined the possible contribution of variations in susceptibility of fish populations, age-related resistance, and virus virulence to the observed landscape heterogeneity. We found that the most significant variable was host susceptibility: by controlled experimental challenge studies steelhead trout populations with no history of IHNV infection were 1 to 3 orders of magnitude more sensitive than a fish population with a long history of IHNV infection. In addition, 2 fish populations from the same river, which descended relatively recently from a common ancestral population, demonstrated 1 to 2 orders of magnitude difference in susceptibility. Fish age-related development of resistance was most evident in the more susceptible of 2 related fish populations. Finally, the strain of virus involved in the 2007 coastal Washington emergence had high virulence but was within the range of other known $\mathrm{M}$ group viruses tested. These results suggest that one major driver of landscape heterogeneity in the 2007 coastal Washington IHNV emergence was variation in fish population susceptibility and that this trait may have a heritable component.
\end{abstract}

KEY WORDS: IHNV $\cdot$ Steelhead trout $\cdot$ Heterogeneous landscape $\cdot$ Host susceptibility

Resale or republication not permitted without written consent of the publisher

\section{INTRODUCTION}

Infectious hematopoietic necrosis virus (IHNV) is a rhabdovirus that causes acute disease and mortality in salmonid fishes. It is endemic in salmonids of Western North America, where it is a significant burden on hatchery-based salmon and trout conservation programs. IHN disease occurs primarily in juvenile fish where it can cause mortality as high as $90 \%$, but asymptomatic adult fish can be observed to have high viral loads at or near the time of spawning; both age classes are capable of transmitting their infection (Mulcahy \& Bauersfeld 1983, Mulcahy et al. 1983a,b, Traxler et al. 1993, Arkush et al. 2004). The primary route of IHNV transmission is horizontal, via waterborne virus (Bootland \& Leong 1999, Mulcahy et al. 1983b). Parents may transmit to their offspring via egg-associated virus, but in hatcheries and fish farms this is usually blocked by egg disinfection, so cultured fish generally start life free of IHNV infection. Horizontal transmission of IHNV into a hatchery is still a risk, as many hatcheries' water supplies contain free-swimming salmonids, which may be infected with IHNV. These 'unsecured' water supplies have been described as likely sources of virus in juvenile IHN disease events (Wolf 1988, Bootland et al. 1994, Bootland \& Leong 1999, Anderson et al. 2000, Breyta et al. 2013). 
Previous studies comparing genetic sequences of many isolates of IHNV from North America have revealed 3 distinct viral genetic groups (Kurath et al. 2003). The M genogroup is found primarily in steelhead and rainbow trout (both Oncorhynchus mykiss) in Washington, Oregon, and Idaho. The U genogroup of IHNV is found primarily in sockeye salmon $O$. nerka in Alaska, British Columbia, Washington, Oregon and Idaho, and in Chinook salmon O. tshawytscha in the Columbia River basin. The L genogroup is found in Chinook salmon of southern Oregon and California. These studies used genetic sequence data from a variable $303 \mathrm{nt}$ segment of the virus glycoprotein gene, called the midG region, for phylogeographic analyses. Each unique midG genetic sequence is called a 'type' and denoted by a universal sequence designator (USD, format mG\#\#\#U/M/L, e.g. type mG110M). Many isolates may have the same type, and when one isolate is used to represent a type in controlled studies it is referred to as a strain. When these midG types are combined with case-detection details like location, age, and species of the infected fish, IHNV transmission pathways can be inferred retrospectively.

Within Washington State, the $\mathrm{U}$ and $\mathrm{M}$ genogroups overlap in some hydrological regions, but not all. Within sections of the Columbia River Basin, U and M genogroup IHNV have co-circulated in steelhead trout for more than 30 yr (Garver et al. 2003). In contrast, fish of Washington's Puget Sound/ Salish Sea region have had only $U$ genogroup viruses over the last 30 yr (Emmenegger \& Kurath 2002) (http://gis. nacse.org/ihnv/; R. Breyta \& G. Kurath unpubl. data). Until recently, IHNV in the Washington Coast region was limited to U genogroup, which caused occasional disease in juvenile sockeye salmon and asymptomatic detection in adult sockeye salmon, as well as sporadic detections in asymptomatic adult steelhead trout, coho salmon, and chum salmon (Emmenegger \& Kurath 2002). This changed when M genogroup viruses emerged in coastal steelhead trout, causing significant disease and mortality at several, but not all, coastal hatcheries: one isolated epidemic occurred in 1997, followed by a sustained series of epidemics between 2007 and 2011 (Breyta et al. 2013). Genetic analyses of virus isolates from these events suggested that there were 3 distinct waves of viral emergence in the region: IHNV type mG111M occurred in 1997; type mG110M occurred during 2007-2009; and type mG139M occurred during 2010-2011. All 3 of these virus types were part of the MD subgroup within the M genogroup, which was first observed in steelhead trout of the lower Columbia River Basin in 1995 (Kurath et al. 2003, Garver et al. 2003). Epi- demiological analysis indicated that each MD virus type observed in a wave of coastal emergence had previously been established as a high prevalence virus type within steelhead trout of the neighboring Columbia River Basin (Breyta et al. 2013).

While a likely geographic source has been identified for the virus types associated with Washington coastal emergence events, an explanation for the heterogeneous distribution of MD subgroup virus detection and disease within the coastal region remains unclear. During the emergence events, MD IHNV was only detected in 4 of 6 coastal watersheds at the hydrologic unit code level 8 (HUC8) (Fig. 1, Table 1). Within

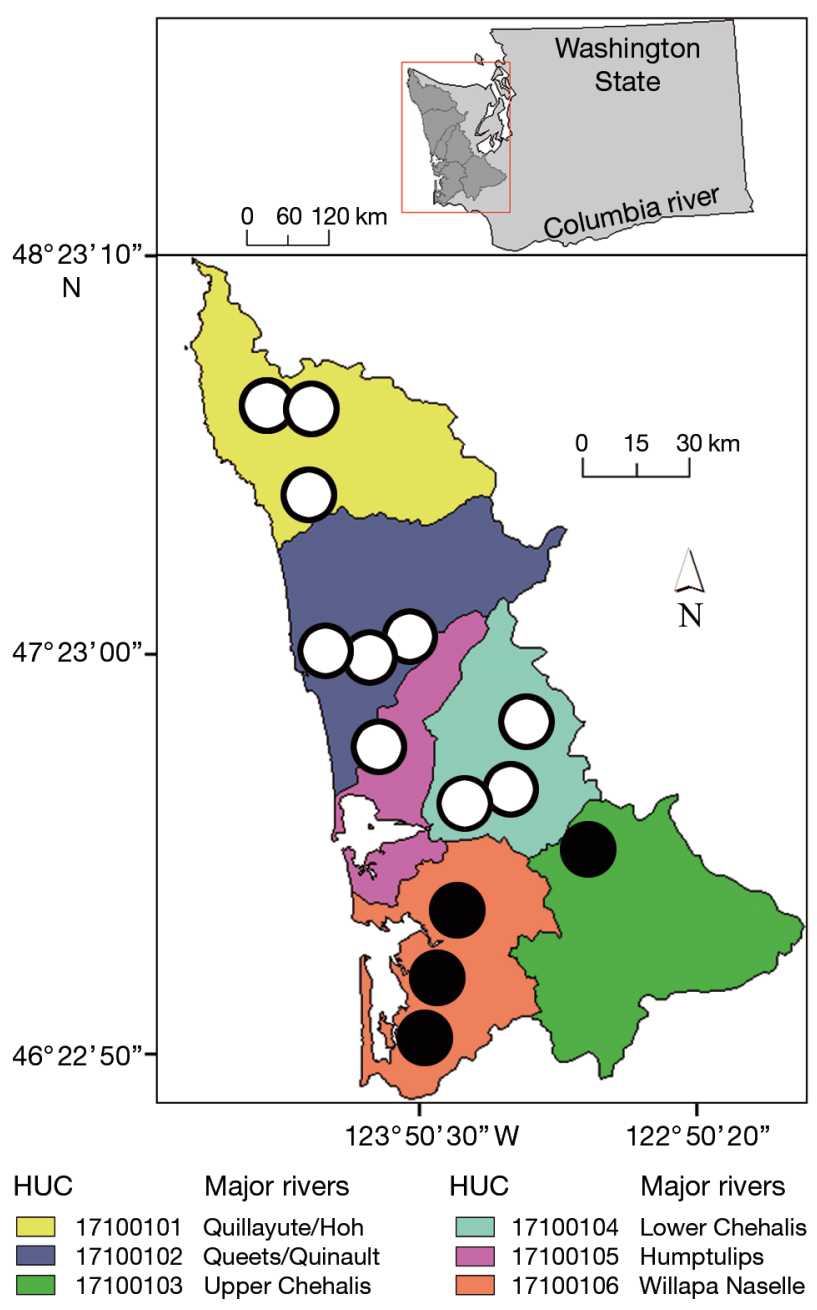

Fig. 1. Geographic location of the 6 National Hydrography Dataset HUC8 coastal watersheds of Washington State, USA. All 6 watersheds contain both wild and cultured steelhead trout (Oncorhynchus mykiss) populations. Open symbols: steelhead trout culture facilities with no detections of MD IHNV; filled symbols: locations where MD IHNV was detected in free-ranging or cultured steelhead trout during the emergence events of 1997 and 2007-2011 (see Table 1 for further details) 
Table 1. Heterogeneous distribution of MD subgroup IHNV types in National Hydrography Dataset Hydrologic Unit Code level 8 watersheds (NHD HUC8; http://nhd.usgs.gov/) of the Washington coast (see also Fig. 1) during MD virus emergence events of 1997, 2007-2009, and 2010-2011 (NB: endemic detections of U group IHNV in salmon programs/sites are not listed). Nature of site indicates whether the detection was in free-ranging $(\mathrm{F})$ or hatchery $(\mathrm{H})$ fish; if hatchery, the security of that hatchery water supply is indicated ('unsecure', hatchery water supply contains many anadromous fish; 'semi-secure', hatchery water supply contains few anadromous fish; 'secure', hatchery water supply is free of anadromous fish, e.g. well water). MD type is as reported in Breyta et al. (2013) or Emmenegger et al. (2002). Juv. dis.: juvenile disease; ad. det.: detection of IHNV in adults; nd: not detected; na: not applicable

\begin{tabular}{|c|c|c|c|c|c|c|}
\hline \multirow[t]{2}{*}{ NHD HUC8 } & \multirow[t]{2}{*}{ Main river } & \multirow[t]{2}{*}{ River(s) affected } & \multirow[t]{2}{*}{ Site type } & \multirow[t]{2}{*}{ MD type } & \multicolumn{2}{|c|}{- Year(s) affected } \\
\hline & & & & & Juv. dis. & Ad. det. \\
\hline \multirow[t]{2}{*}{17100101} & Quillayute & Bogachiel & $\mathrm{H}$, secure & $\mathrm{mG} 139 \mathrm{M}$ & na & 2010 \\
\hline & Hoh & Hoh & $\mathrm{F}$ & $\mathrm{mG} 139 \mathrm{M}$ & na & 2010 \\
\hline \multirow[t]{6}{*}{17100102} & Queets & Queets & $\mathrm{H}$, unsecure & $\mathrm{mG} 111 \mathrm{M}$ & 1997 & nd \\
\hline & & & & $\mathrm{mG} 110 \mathrm{M}$ & 2007 & nd \\
\hline & & & & $\mathrm{mG} 139 \mathrm{M}$ & 2010-2011 & nd \\
\hline & Quinault & Quinault, tribal & $\mathrm{H}$, unsecure & $\mathrm{mG} 110 \mathrm{M}$ & 2008 & 2008-2009, 2011 \\
\hline & & & & mG139M & 2010 & $2010-2011$ \\
\hline & Quinault & Quinault, federal & H, semi-secure ${ }^{*}$ & mG139M & 2010 & $2010-2011$ \\
\hline 17100103 & Upper Chehalis & nd & & na & na & na \\
\hline \multirow[t]{2}{*}{17100104} & Lower Chehalis & Wynoochee & $\mathrm{H}$, unsecure* & $\mathrm{mG} 110 \mathrm{M}$ & 2007 & $2007-2009$ \\
\hline & & Satsop & $\mathrm{H}$, secure & $\mathrm{mG} 110 \mathrm{M}$ & 2007 & $2007-2009$ \\
\hline 17100105 & Humptulips & Humptulips & H, semi-secure ${ }^{*}$ & $\mathrm{mG} 110 \mathrm{M}$ & 2008 & $2007-2010$ \\
\hline 17100106 & Willapa/ Naselle & nd & & na & na & na \\
\hline
\end{tabular}

these 4 watersheds, the timing and severity of impact was also heterogeneous: in the Queets/Quinault system juvenile IHN disease and/or asymptomatic adult detections were associated with all 3 waves of virus emergence; within the Humptulips and Lower Chehalis watersheds juvenile IHN disease and asymptomatic adult detections were only detected during the second wave of virus; and in the Quillayute/Hoh watershed asymptomatic adult detections, with no disease events at all, were only apparent in the third wave of virus emergence. Furthermore, it is unclear why some rivers lying close to the probable source of MD IHNV in the Columbia River (e.g. Willapa/ Naselle watershed 17100103) did not acquire MD IHNV, but more distant rivers were affected many times (e.g. Queets/Quinault watershed 17100102).

In addition to large-scale watershed heterogeneity during the viral emergence events, hatcheries with unsecured water supplies known to contain viruspositive adult fish did not always suffer transmission and disease. In other words, if having infected adult fish in the water supply of a hatchery was always predictive of transmission into that hatchery's susceptible juvenile fish, some hatcheries should have suffered juvenile fish disease more often than observed (Table 1, asterisks). These differential impacts of disease were especially apparent within the Quinault River. This river contains 2 different hatchery populations of steelhead trout: a federal and a tribal hatchery population. Both hatchery populations were derived from the native wild population about $40 \mathrm{yr}$ ago and have since been managed differently. During the emergence events of 2007-2011, there were different impacts of virus on the 2 hatchery populations. The Lake Quinault (LQ) tribal hatchery steelhead trout suffered epidemic disease during the wave of mG110M type IHNV in 2008, and also during the wave of mG139M type IHNV in 2010 (Table 1). In each of these cases IHN disease occurred when the juvenile LQ fish were 3-4 mo of age. In contrast, the Quinault National (QN) federal hatchery steelhead trout only suffered elevated mortality once, during the wave of $\mathrm{mG} 139 \mathrm{M}$ in 2011 (Table 1), when the QN fish were 11-12 mo of age. Thus, although type $\mathrm{mG} 110 \mathrm{M}$ virus was in migrating adult fish in the river in 2008, juvenile disease occurred in only one of the 2 cultured populations of the Quinault River. Similar patterns of lack of transmission to juveniles despite presence of a virus source were observed at 2 other hatcheries during the coastal emergence events (Table 1, asterisks), suggesting that factors other than presence of virus contribute to the development of disease.

These heterogeneous impacts of IHNV during the Washington coastal emergence events might be influenced by many ecological, biological, or anthro- 
pogenic factors. The present study tested the potential role(s) of variations in susceptibility of different steelhead trout populations; development of age-related resistance; or virulence of invading virus types. Published reports have indicated that variation exists in all 3 parameters for IHNV, but none of these reports describe observations in steelhead trout populations. For example, inter-species variation of IHNV susceptibility exists between Chinook, coho, sockeye, and kokanee salmon, and steelhead/rainbow trout (Wingfield et al. 1970a,b, Chen et al. 1990, LaPatra et al. 1990, 1993), and intra-species variation among different populations of Chinook salmon, sockeye salmon, and rainbow trout has also been described (Amend \& Nelson 1977, Wertheimer \& Winton 1982, Chen et al. 1990, Garver et al. 2006, Purcell et al. 2009, 2010, Peñaranda et al. 2009). Age-related differential susceptibility has been described in kokanee salmon and rainbow trout (Bergmann et al. 2003). Finally, different genetic types of IHNV have different levels of hostspecific virulence in sockeye salmon and/or rainbow trout (LaPatra et al. 1993, Troyer \& Kurath 2003, Garver et al. 2006, Peñaranda et al. 2009, Purcell et al. 2009, Wargo et al. 2010). We examined these factors in pertinent steelhead trout stocks, to infer whether host population, age, and/or virus virulence were potential ecological drivers in the Washington coastal emergence events of 1997 and 2007-2011.

Controlled laboratory studies were performed in 2009 and 2010 (before the third coastal wave was apparent) to quantify the relative susceptibility within $30 \mathrm{~d}$ of exposure of juvenile fish from 5 different steelhead trout populations to the MD type strain Qts07. This strain was selected to represent the mG110M type that was responsible for the second wave of viral emergence in 2007-2009. This was the first MD type detected at more than one coastal site, and it demonstrated geographic heterogeneity in the coastal region (Table 1). Due to the heterogeneous impact of this type in the Quinault River, the 2 steelhead trout populations from the Quinault River were the primary focus of the study. Therefore these 2 stocks of fish were also tested at a larger size to determine how fish size or age influenced susceptibility to the same strain of IHNV. Additional studies were conducted in the same 2 steelhead trout populations to compare relative virulence of the Qts07 strain with 4 other IHNV strains. Data from these studies were analyzed by linear regression and survival analysis and indicated that there were significant differences among steelhead trout populations, and between fish of different size, in susceptibility to the Qts07 strain. However, there were only subtle differences in relative virulence of MD strains of IHNV. These results suggest that Washington coastal IHNV emergence events are more strongly driven by complex patchworks of host susceptibility than variation of viral virulence.

\section{MATERIALS AND METHODS}

\section{Virus isolates}

The Qts07 strain (type mG110M) used for 9 of the 11 challenge studies was isolated from epidemic juvenile steelhead trout at a hatchery on the Queets River in 2007, and was provided by J. Bertolini (Northwest Indian Fisheries Commission). Virus strains for comparative virulence testing were selected to represent other M group virus types involved in Columbia River and/or coastal Washington emergence events, as well as reference strains from the $\mathrm{M}$ and $\mathrm{U}$ genogroups with known high and low virulence in O. mykiss (Table 2). The M genogroup reference strain 220-90 (type mG009M) was isolated from rainbow trout in 1990 and is highly virulent in that host (LaPatra et al. 1991, Garver et al. 2006, Wargo et al. 2010), and the U genogroup strain BLk94 (type mG002U) was isolated from Baker Lake sockeye salmon in 1994 and has low virulence in O. mykiss (Emmenegger \& Kurath 2002, Garver et al. 2006, Peñaranda et al. 2009). The LR80 strain (type mG007M) was provided by J. Winton and has been described (Nichol et al. 1995). The Mer95 strain (type mG111M) was isolated from steelhead trout in the Columbia River basin in 1995 and was provided by J. Thomas (Washington Dept. Fish and Wildlife). Viruses were propagated in the epithelioma papilosum cyprinid (EPC) fish cell line at multiplicity of infection of $0.01-0.001$ (Fijan et al. 1983) at $15^{\circ} \mathrm{C}$ and titered by plaque assays as previously described (Batts \& Winton 1989). Experimental fish that died were titered to confirm IHNV as cause of death using the plaque assay with a lower limit of detection of 100 plaque-forming units per $\mathrm{g}\left(\mathrm{PFU} \mathrm{g}^{-1}\right)$.

\section{Steelhead trout populations and rearing conditions}

The 5 populations used in challenges were selected from geographic regions that differ in historical IHNV burden (Table 3). Steelhead trout populations were obtained as follows: LQ eggs were provided by T. Jurasin (Quinault Nation, operator of the Lake Quinault Tribal Fish Hatchery); QN eggs were provided by B. Edwards (US Fish and Wildlife Service, operator of the Quinault National Fish Hatchery); 
Table 2. IHNV isolates used in controlled animal studies. USD: universal sequence designator (Emmenegger \& Kurath 2002), specifies individual IHNV sequence types within the major IHNV genogroups, based on the 303 nt midG region within the viral glycoprotein gene; WA: Washington; CRB: Columbia River Basin; Coast: Washington State Pacific coastal watersheds; ID: Idaho. $\mathrm{MD}$ and $\mathrm{MB}$ are phylogenetically defined subgroups within the $\mathrm{M}$ genogroup; and $\mathrm{U}$ indicates a sequence type within the U genogroup

\begin{tabular}{|c|c|c|c|}
\hline IHNV strain & USD & Geographic origin & Rationale for inclusion \\
\hline LR80 & $\mathrm{mG} 007 \mathrm{M}$ & WA, Lower CRB & $\begin{array}{l}\text { Type from M genogroup that emerged in lower CRB steelhead from } \\
1980-1994 \text {; never detected in coastal WA }\end{array}$ \\
\hline Mer95 & $\mathrm{mG} 111 \mathrm{M}$ & WA, Lower CRB & $\begin{array}{l}\text { Type from MD subgroup that emerged in lower CRB steelhead from } \\
1994-1999 \text {; first wave of coastal MD IHNV emergence } 1997\end{array}$ \\
\hline Qts07 & $\mathrm{mG} 110 \mathrm{M}$ & WA coast & $\begin{array}{l}\text { Type from MD subgroup that emerged in lower CRB steelhead 2002- } \\
\text { present; second wave of coastal MD IHNV emergence in 2007-2009 }\end{array}$ \\
\hline $220-90$ & mG009M & ID, Hagerman Valley* & $\begin{array}{l}\text { Type from MB subgroup IHNV with high virulence in rainbow trout; } \\
\text { never detected in coastal WA }\end{array}$ \\
\hline BLk94 & $\mathrm{mG} 002 \mathrm{U}$ & WA, Puget Sound & $\begin{array}{l}\text { Type from U genogroup IHNV with low virulence in rainbow trout; spo- } \\
\text { radically detected in coastal WA }\end{array}$ \\
\hline
\end{tabular}

Table 3. Washington state steelhead trout (Oncorhynchus mykiss) populations used in controlled animal studies. Coast: Washington State Pacific coastal watersheds; R: river; CRB: Columbia River Basin

\begin{tabular}{|c|c|c|c|}
\hline Fish pop. & Code & Geographic origin & Rationale for inclusion \\
\hline Lake Quinault & LQ & Coast, Quinault R. & $\begin{array}{l}\text { Suffered major losses in second and third waves of coastal IHNV emer- } \\
\text { gence; hatchery-adapted steelhead trout }\end{array}$ \\
\hline Quinault National & $1 \mathrm{QN}$ & Coast, Quinault R. & $\begin{array}{l}\text { Suffered minor losses in third wave of coastal IHNV emergence; hatch- } \\
\text { ery-adapted steelhead trout }\end{array}$ \\
\hline Elwha-Chambers & $\mathrm{EC}$ & Puget Sound, Elwha R. & $\begin{array}{l}\text { Geographically adjacent to coastal region, naïve for IHNV exposure } \\
\text { hatchery-adapted steelhead trout }\end{array}$ \\
\hline Elwha-Wild & EW & Puget Sound, Elwha R. & $\begin{array}{l}\text { Geographically adjacent to coastal region, naïve for IHNV exposure; } \\
\text { native wild steelhead trout }\end{array}$ \\
\hline Skamania & SK & Lower CRB & $\begin{array}{l}\text { Long history of IHNV infection and juvenile losses; hatchery-adapted } \\
\text { steelhead trout }\end{array}$ \\
\hline
\end{tabular}

Elwha-wild and Elwha-Chambers (EW and EC) eggs were provided by L. Ward (Lower Elwha Klallam Tribe, operator of Elwha Tribal Fish Hatchery); and Skamania (SK) eggs were provided by J. Allen (Washington Dept. of Fish and Wildlife, operator of the Skamania State Fish Hatchery). Eggs from each population were pooled from no fewer than 12 pairs of male/female parents to ensure a broad genetic representation of the population and to minimize potential for a founder susceptibility effect. Eyed eggs were transported, disinfected, and reared in the wet laboratory facilities of the Western Fisheries Research Center (WFRC). Eggs and fish were reared indefinitely in single-pass flow through $10^{\circ} \mathrm{C}$ filtered and UV-treated lake water and fed a moist pellet diet from Skretting at a feed rate of 1.0-1.5\%. All fish were constantly monitored for consistent health; no diagnostic tests were performed before challenge with IHNV. All challenge studies were performed with a constant water temperature of $10^{\circ} \mathrm{C}$.

\section{Immersion challenge studies}

A total of 11 different controlled laboratory challenges were performed in 2009 and 2010. In 2009, 2 challenges were conducted to compare the lethal dose $\left(\mathrm{LD}_{50}\right)$ estimates for 2 populations from the Quinault River, LQ and QN, using the immersion challenge method for small fish (described below). Also in 2009, 2 challenges were conducted to compare the LQ and QN populations for their relative susceptibility to 5 different virus strains using the immersion challenge method for comparative virulence. Later in 2009, 2 challenges were conducted to compare the $\mathrm{LD}_{50}$ estimates from the LQ and $\mathrm{QN}$ populations when the fish were larger using the immersion challenge method for larger fish (described below). Subsequently in 2010, eggs from the same 2 Quinault River populations and 3 additional fish populations were acquired, and 5 challenges were conducted to compare $\mathrm{LD}_{50}$ estimates for 
populations from a wider geographic distribution using the immersion challenge method for small fish. The results of these 11 challenges are presented in a different structure than the sequential order of experiment performance, however, in order to facilitate the comparisons that are most salient: mortality kinetics for all 9 challenges in small and large fish are shown together in Fig. 2; estimates of $\mathrm{LD}_{50}$ and p-values from the same 9 challenges are shown together in Fig. 3 ; the mortality kinetics and $\mathrm{LD}_{50}$ estimates of 5 different viruses in the 2 LQ and QN fish populations is shown in Fig. 4.

$$
\mathrm{LD}_{50} \text { for small juvenile fish }
$$

In both 2009 and 2010, fish from each population were reared for 3 mo after yolk sac absorption, to an average size of $\sim 3 \mathrm{~g}$, before challenge. Each fish population was tested independently, as the fish reached this target size. Batch challenge of triplicate tanks of 25 randomly selected fish for each virus dose, or mock treatment, was conducted by the immersion method as previously reported (Garver et al. 2006). Briefly, fish were counted into 11 of static, temperature controlled water with aeration before virus or mock solutions were added. Exposures consisted of 4 virus doses $\left(200,2000,20000\right.$, and $200000 \mathrm{PFU} \mathrm{ml}^{-1}$ ) of the Qts07 virus stock or cell culture media alone, for $1 \mathrm{~h}$ before water flow was restored to the full volume of $4 \mathrm{l}$. All tanks were monitored daily for mortality for $30 \mathrm{~d}$. From the fish that died during the challenge, $20 \%$ were randomly selected to be analyzed by plaque assay for detection and quantification of virus in exposed or control groups. Results are shown in Fig. 2A, C,D,F-I.

\section{$\mathrm{LD}_{50}$ for larger fish}

In 2009, LQ and QN fish were reared to 11 mo of age, to an average size of 10-11 g, for fish age-related resistance comparisons. Batch challenge of triplicate tanks of 25 fish was conducted by $1 \mathrm{~h}$ immersion in $5 \mathrm{l}$ of static water containing the Qts07 virus at each of 2 doses (2000 and $200000 \mathrm{PFU} \mathrm{m}^{-1}$ ) in addition to mock exposure. Since rainbow trout has been described to have greater resistance to IHNV strains at a larger and/or older stage, a high and intermediate virus dose was selected for challenge. After challenge water flow was restored to a full volume of $30 \mathrm{l}$ per tank, and fish were monitored daily as described above. Results are shown in Fig. 2B,E.

\section{Virulence comparison between 5 virus strains}

LQ and QN fish were reared to 4 mo of age, to an average size of $3.5 \mathrm{~g}$, for comparison of relative virulence of 5 different virus strains (Table 2). Batch immersion challenge of triplicate tanks of 25 fish was conducted as above in 11 of static water, with each virus strain tested at 2 doses (2000, and 200000 PFU $\mathrm{ml}^{-1}$ ) in addition to mock exposure, for each fish population. After challenge water flow was restored to a full volume of $4 \mathrm{l}$ per tank, and fish were monitored daily as described above. Results are shown in Fig. 4A-D.

\section{Statistical analysis}

$\mathrm{LD}_{50}$ values were calculated by 2 methods. One was the long-established Reed-Muench (RM) method (Reed \& Muench 1938), which requires observed mortality levels to bracket the desired dose-mortality value (i.e. to calculate an $\mathrm{LD}_{50}$ value, mortality levels both above and below $50 \%$ must be observed). This method does not produce an estimate of standard error. The second method uses a Generalized Linear Model (GLM) as implemented in the R statistical program using the dose.p function of the Mass package, with a quasibinomial distribution prior (Venables \& Ripley 2002). This method allows estimates of dosemortality points that lie outside the observed mortality levels and provides the uncertainty around those estimates (the standard error and 95\% confidence interval, CI). Significant differences between GLM $\mathrm{LD}_{50}$ values were calculated by the Welch-Satterthwaite (W-S) 2-tailed t-test correction in R. Survival analysis used the Cox proportional hazards method to test the significance of the covariates of fish population, fish size, and virus strain on risk of death after exposure to virus. Survival analysis was conducted using the Survival package of R (Therneau \& Grambsch 2000), with a type 1 right-censor prior and likelihood ratio test for significance.

\section{RESULTS}

\section{Two closely related steelhead trout populations differ in susceptibility to IHNV MD Qts07}

To determine if a contributing factor to the difference of IHNV burden between the LQ and QN steelhead trout populations was an inherent difference in susceptibility of the fish, the $\mathrm{LD}_{50}$ of Qts07 virus was determined for these steelhead populations using 
2009 juvenile fish at an age of 3 mo. Cumulative percent mortality (CPM) over the $30 \mathrm{~d}$ course of the experiment followed a dose-response pattern, and mock-exposed groups suffered no more than $3 \%$ mortality (Fig. 2A,D). Onset of mortality occurred on Day 6 in LQ fish and Day 8 in QN fish. Daily mortality was greater in LQ fish than in QN fish, making the kinetics of infection-induced mortality much faster in the LQ population, and leading to higher final cumulative mortality (Fig. 2A,D). A randomly selected subset of fish that died in each challenge was tested for virus: in 2009 all mortalities tested from virus-exposed groups had detectable virus ranging from $3.0 \times 10^{2}$ to $1.9 \times 10^{7} \mathrm{PFU} \mathrm{g}^{-1}$, and no mock-exposed mortalities had detectable virus (further investigation of cause of death was not performed as a low level of mortality is not unexpected in salmonid juveniles); in 2010 all virus-exposed mortalities tested had infectious virus ranging from $1.7 \times 10^{4}$ to $1.7 \times 10^{7} \mathrm{PFU} \mathrm{g}^{-1}$, and no mock-exposed mortalities had detectable virus.
The $\mathrm{LD}_{50}$ values calculated by both GLM and RM methods produced very similar $\mathrm{LD}_{50}$ estimates (Fig. 3A). While the RM method produced values that were slightly lower than the GLM point-estimates, the RM values always fell within the $95 \%$ CI of the GLM estimates. Statistical comparison of the GLM $\mathrm{LD}_{50}$ values indicated that the LQ fish were significantly more susceptible than QN fish (Fig. 3A).

\section{Older LQ steelhead trout are more resistant to IHNV MD Qts07}

To determine if the LQ or QN populations differed in development of age-related resistance to IHN, 11 mo old fish from each population were challenged with Qts07 virus at 2 different doses. As in the smaller fish, mortality followed a dose-response pattern, and mortality was no more than $3 \%$ in the mock-exposed groups (Fig. 2B,E). Onset of mortality occurred on Day 8 in
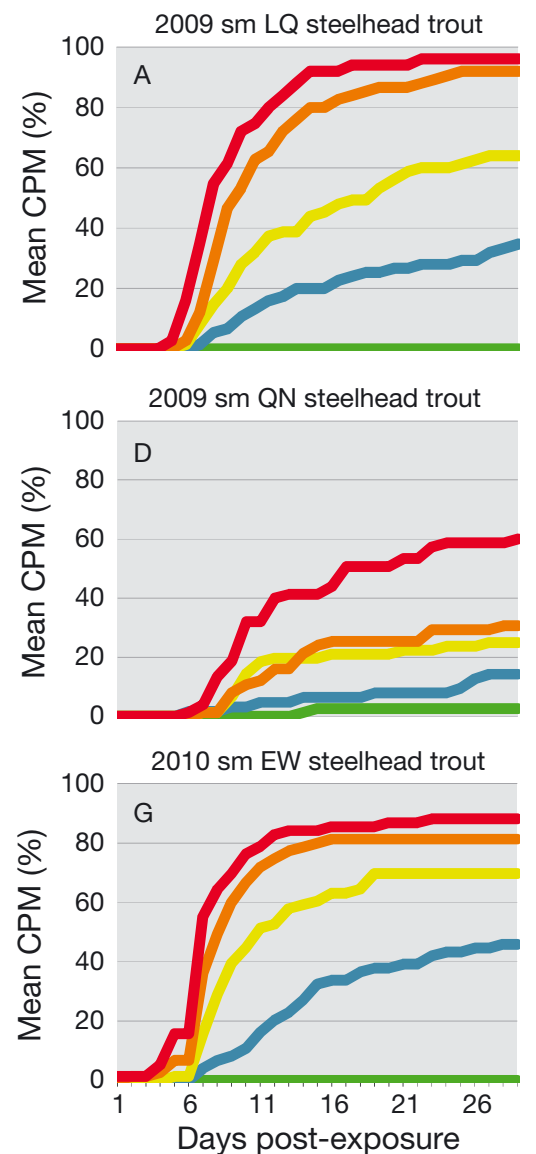

2009 Ig LQ steelhead trout

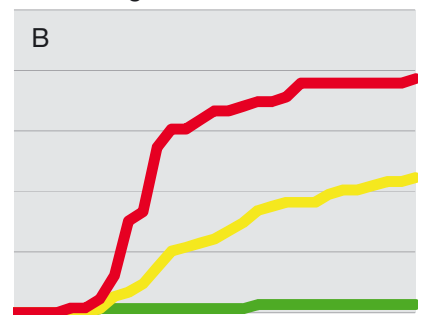

2009 Ig QN steelhead trout

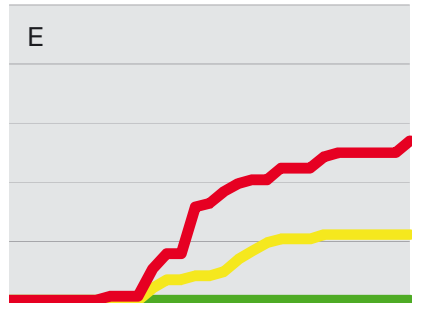

2010 sm EC steelhead trout

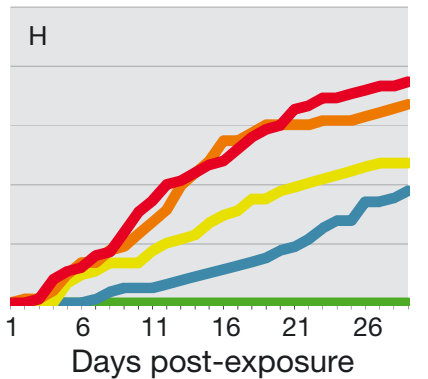

2010 sm LQ steelhead trout

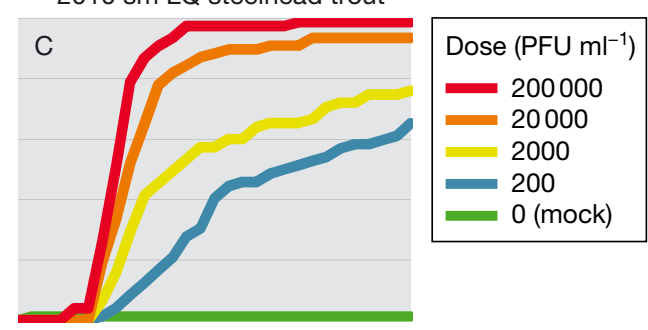

2010 sm QN steelhead trout

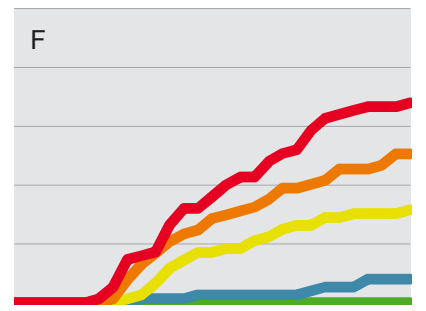

2010 sm SK steelhead trout

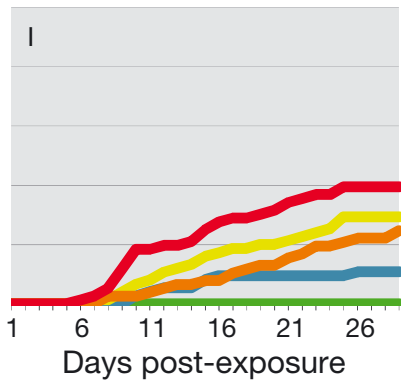

Fig. 2. Steelhead trout (Oncorhynchus mykiss) average cumulative percent mortality (CPM) from 9 different immersion challenges using 5 different populations (codes as in Table 3) to compare levels and kinetics of mortality. Fish were mockchallenged or exposed to virus doses from 200 to $200000 \mathrm{PFU} \mathrm{ml}^{-1}$. In 2009 steelhead trout from the (A,B) LQ and (D,E) QN populations were tested in (A,D) 'small' 3 mo old (3 g) fish, and (B,E) 'large' 11 mo old (11 g) fish. In 2010, only small steelhead trout from (C) LQ, (F) QN, (G) EW, (H) EC, and (I) SK populations were tested 

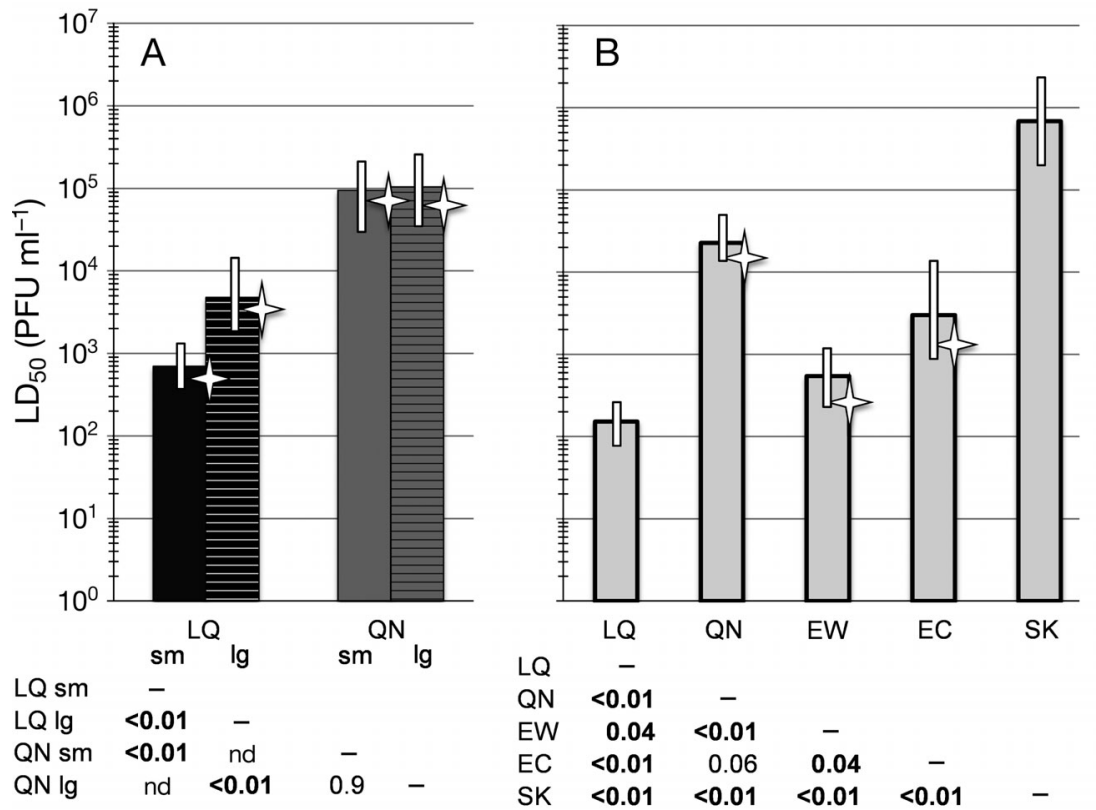

Fig. 3. Lethal dose $\left(\mathrm{LD}_{50}\right)$ values for various Washington state steelhead trout (Oncorhynchus mykiss) populations and fish ages calculated from the data shown in Fig. 2 by generalised linear modeling (GLM; bars, with 95\% confidence intervals), and by the Reed-Muench method (stars) (see 'Materials and methods: Statistical analysis'). (A) In 2009, tests were conducted in 'small' (sm, solid bars) 3 mo old ( $3 \mathrm{~g})$ and 'large' (lg, stippled bars) 11 mo old (11 g) fish from the LQ and QN populations (codes as in Table 3). (B) In 2010, tests were conducted using only small fish from the LQ, QN, EW, EC, and SK populations. Differences between biologically relevant pairs of GLM LD $\mathrm{L}_{50}$ values were tested using the Welch-Satterthwaite $t$-test; $\mathrm{p}$-values shown in matrices below each graph, with significant differences $(p<0.05)$ in bold; nd: not done older LQ fish and Day 11 in older QN fish, a delay of 2$3 \mathrm{~d}$ compared to the younger fish. Mortality kinetics and final CPM was greater in LQ fish than in QN fish.

The $\mathrm{LD}_{50}$ values calculated by both methods showed the same pattern of the lower RM point estimate falling within the $95 \%$ CI of the GLM method (Fig. 3A). The GLM LD 50 values were higher in large fish than small fish for both the LQ and QN populations, but this was only significant for the LQ population (Fig. 3A; $\log$ scale obscures the difference in values for QN where small fish $\mathrm{LD}_{50}$ was $9.5 \times 10^{4}(2.4 \times$ $10^{4}$ to $3.7 \times 10^{5}$ ) PFU ml ${ }^{-1}$ and large fish $\mathrm{LD}_{50}$ was 1.0 $\times 10^{5}\left(3.6 \times 10^{4}\right.$ to $\left.\left.3.0 \times 10^{5}\right) \mathrm{PFU} \mathrm{ml} \mathrm{m}^{-1}\right)$. This indicates that significantly more Qts07 virus was necessary to cause mortality in older fish only in the more susceptible LQ population. Survival analysis indicated that fish age was a significant covariate of the risk of death in LQ fish only $(p<0.01)$.

\section{Additional steelhead trout populations vary in susceptibility to IHNV MD Qts07}

To determine if steelhead trout populations from regions with naïve, newly emerged, or endemic IHNV histories differ in susceptibility to the mG110M type Qts07 strain, $L_{50}$ experiments were performed again with the LQ and QN as well as 3 additional steelhead trout populations (Table 3) in 2010 in fish that were 3 mo old. The EW and EC populations are from the same site in the Puget Sound where neither M nor U group IHNV has ever been detected; both derive from the native wild steelhead trout of the Elwha River.
The SK population comes from the Columbia River Basin, where IHNV has been endemic for over $30 \mathrm{yr}$, and where the mG110M has been detected many times in small fish since 2002. Mortality in all 5 experiments followed a dose-response pattern, and mortality in the mock exposed control groups was no more than $1 \%$ (Fig. 2C,F-I). The mortality was slightly higher overall in both LQ and QN in 2010 compared to 2009, but the results were consistent in that a clear dose response was observed, and mortality was again faster, and to higher final levels, in the LQ fish. Among the other 3 fish populations, onset of mortality occurred on Day 3 in both EW and EC fish, and on Day 8 in SK fish. Mortality kinetics was fastest in EW fish, and slower in EC fish despite reaching only slightly lower levels of final CPM. The SK fish had the lowest and slowest mortality. A randomly selected subset of dead fish was tested for virus: all mortalities from virus-exposed groups had detectable virus (ranging from $2.4 \times 10^{3}$ to $8.5 \times 10^{6} \mathrm{PFU} \mathrm{g}^{-1}$ ), and no mock-exposed mortalities had detectable virus.

$\mathrm{LD}_{50}$ values were calculated by both GLM and RM methods where possible; in LQ fish no dose yielded less than $50 \%$ mortality, and in SK fish no dose yielded above $50 \%$ mortality (Fig. 3B). For the other 3 steelhead trout populations the RM method produced $\mathrm{LD}_{50}$ values that were lower than the GLM point-estimates, but all were within the $95 \%$ CI of the GLM estimates. The wild native steelhead trout EW population was significantly more susceptible than the hatchery-adapted EC population, which is reared at the same location $(p=0.04)$. Compared to the LQ and QN stocks, the EC and EW populations demon- 

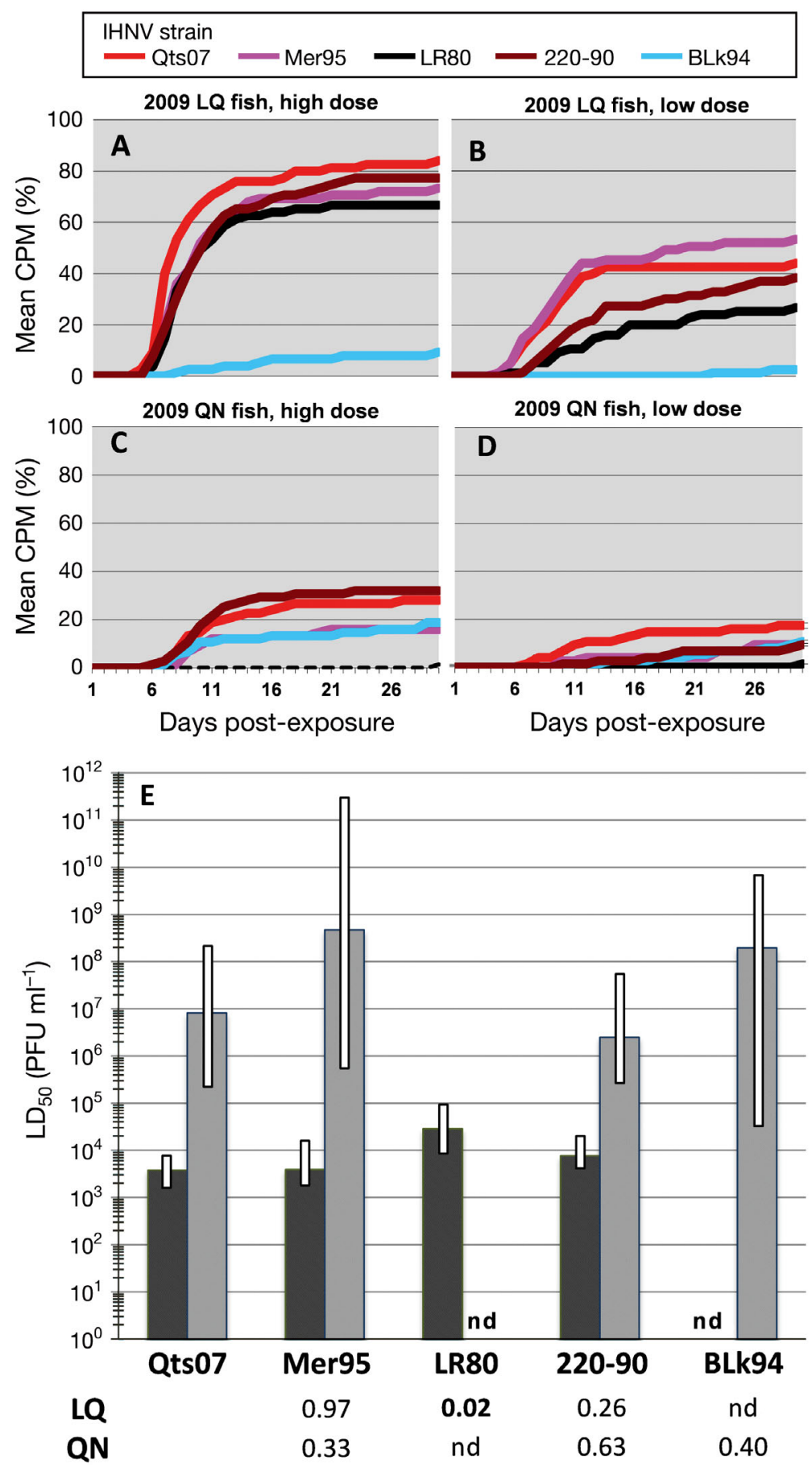

Fig. 4. Relative virulence of 5 strains of IHNV in LQ and QN steelhead trout Oncorhynchus mykiss (population codes as in Table 3). Average CPM in triplicate groups of $(A, B) L Q$ or $(C, D)$ QN fish is shown after immersion exposure to virus strains Qts07, Mer95, LR80, 220-90, and BLk94 (see Table 2) at $(\mathrm{A}, \mathrm{C})$ high $\left(200000 \mathrm{PFU} \mathrm{m} \mathrm{m}^{-1}\right)$ or $(\mathrm{B}, \mathrm{D})$ low $(2000 \mathrm{PFU}$ $\mathrm{ml}^{-1}$ ) dose. Fish were approximately 4 mo old at time of challenge with an average weight of $3.5 \mathrm{~g}$. (E) Where mortality was sufficient for calculation, the GLM LD 50 estimate is shown for each virus in both LQ (black hatch) and QN (grey hatch) fish. Significant differences between GLM $\mathrm{LD}_{50}$ values of Qts07 virus and the other 4 strains were tested using the Welch-Satterthwaite $t$-test and shown as in Fig. 3 strated intermediate levels of susceptibility. The EC population is significantly more resistant to Qts07 than the LQ population ( $\mathrm{p}<0.01$ ), but not significantly different from the $\mathrm{QN}$ population $(\mathrm{p}=0.06)$. The wild native EW stock was significantly more susceptible to Qts07 than the LQ population $(p=0.04)$. The IHNVendemic SK population was significantly less susceptible to Qts07 than all other fish populations tested (all $\mathrm{p}<0.01$ ).

\section{Coastal emergent Qts07 strain is not more virulent than known high virulence IHNV strains}

To determine if the coastal strain Qts07 with type mG110M that emerged in 2007 was particularly virulent (here defined as producing a significantly lower $\mathrm{LD}_{50}$ value) compared to other $\mathrm{M}$ or $\mathrm{U}$ group viruses, comparative virulence experiments were performed in the LQ and QN steelhead trout populations. Two virus doses of each of 5 IHNV strains (Table 2) were tested, in addition to mock-exposure. Mortality in both experiments followed a dose-response pattern (Fig. 4) and mortality was no more than $3 \%$ in the mock exposed control groups. Onset of mortality from all virus strains occurred on Day 6 in LQ fish, and on Day 8 in QN fish. Mortality kinetics were higher and faster in LQ fish than in QN fish, with one exception: the U group BLk94 strain caused lower mortality in the LQ fish, but the average mortality caused by this strain was below $20 \%$ in both populations, at both challenge doses. In the LQ population all $4 \mathrm{M}$ genogroup strains caused higher mortality than the U genogroup BLk94 reference strain, as expected (Fig. 4A,B). However, in the more resistant QN population, where final mortality levels in all treatment groups were less than $33 \%$, this trend was not as evident, especially for the Mer95, which caused similar mortality as the U genogroup BLk94, and for the LR80 M genogroup strain which caused almost no mortality. A randomly selected subset of dead fish was titered for virus: mortalities from virus-exposed groups had 
detectable virus up to $3.0 \times 10^{7} \mathrm{PFU} \mathrm{g}^{-1}$, and no mockexposed mortalities had detectable virus.

Using only the GLM method, $\mathrm{LD}_{50}$ values were calculated for each virus in each fish population; the values have low precision or were not calculable in the cases of LQ fish exposed to BLk94 virus and QN fish exposed to LR80 virus (respectively) due to the very low levels of mortality observed (Fig. 4E, nd). As in experiments with Qts07 alone, LQ fish were far more susceptible to all M group strains than QN fish. Comparisons of Qts07 with the other 4 virus strains revealed that within the LQ population, the Qts07 strain was equivalent in virulence to the high-virulence M group reference strain 220-90 and the Mer95 strain, and it was significantly more virulent than LR80 ( $p=0.02)$ and the low-virulence U group reference strain BLk94 (by CPM). Within the QN population, the Qts07 strain did not differ in virulence from the M genogroup reference 220-90 strain, the Mer95 strain, or the U genogroup reference strain BLk94 (Fig. 4E). The Qts07 strain was more virulent in QN fish than the LR80 strain by CPM.

\section{DISCUSSION}

The incidence and severity of MD group IHNV viruses was highly heterogeneous in steelhead trout populations of the Washington coast region between 2007-2011. Only some hatcheries had fish populations that suffered disease and death due to IHNV. While the security of hatchery water supplies has been identified as a risk factor (Bootland et al. 1994, Bootland \& Leong 1999, Anderson et al. 2000, Breyta et al. 2013), this did not sufficiently explain why some fish populations that were likely exposed still did not suffer significant mortality. In this report we have demonstrated more significant variations in host susceptibility, rather than significantly higher virulence of the emergent type mG110M compared to other virus strains. This suggests that instead of an extremely virulent emergent virus, variations in host susceptibility may have driven the heterogeneous occurrence and mortality observed during the coastal emergence of MD group IHNV in 2007-2011.

The host factor that demonstrated the most significant variation in susceptibility was fish population. Among 5 different fish populations tested there was over a 1000-fold range of the dose of Qts07 virus needed to kill half of exposed fish (Fig. 3). Of the $10 t$ tests performed, 9 showed significant differences. The LQ and QN steelhead trout populations differed more than 100-fold, despite being derived recently from the same wild population within the same river. In 2008, migratory adult fish in the Quinault River were found infected with IHNV type mG110M, but only juvenile LQ fish suffered mortality from the virus, while juvenile QN fish did not (Table 1). This may be due, at least in part, to the semi-secure water supply for the QN hatchery, which has a weir that significantly reduces entry of migratory fish into the hatchery water supply. The LQ hatchery water is unsecure as it is taken directly from the nearby Lake Quinault, which contains several populations of migratory salmonids. However, results described here indicate that the LQ population was also significantly more susceptible than QN fish to rapid mortality caused by the mG110M type strain Qts07. Additionally, the LQ fish were more susceptible to mortality caused by 3 other M group IHNV virus strains tested. The LQ and QN steelhead trout populations were both derived from the same wild winter steelhead trout population approximately $40 \mathrm{yr}$ ago and have been propagated differently since then: spawning LQ steelhead trout have been selected for older, larger fish (those that spent 3 yr in saltwater instead of $2 \mathrm{yr}$ ), while spawning QN fish have been selected for younger, earlier returning fish (2-3 mo earlier return than LQ fish) (T. Jurasin, Quinault Nation; and S. Mumford, US Fish and Wildlife Service, pers. comm.). The relatively recent common origin of these 2 populations and the significant difference in their susceptibility to $M$ group IHNV viruses suggests that there may be some degree of heritable virus-resistance that is linked to other traits under selection.

In addition to this evidence linking fish population history to IHNV susceptibility, there also appears to be a correlation between historic IHNV exposure and susceptibility. The Skamania population of steelhead trout from the lower Columbia River basin was the most resistant to mortality caused by the mG110M type strain Qts07. M group IHNV was first detected at the Skamania hatchery in 1994 and has been detected in juvenile SK steelhead trout every year between 2002-2011 (G. Kurath \& R. Breyta unpubl. data). Epidemic IHN disease is not unusual in this population, and so when disease occurs it is allowed to run its course, and surviving fish are released (J. Kerwin, Washington Dept. of Fish and Wildlife, pers. comm.). In contrast, $\mathrm{M}$ group IHNV, including type $\mathrm{mG110M}$, had never been detected before 2008 in the LQ population, and it has never been detected at all in the QN, EC, and EW populations. All 4 of these historically naïve populations were far more sensitive to the mG110M type Qts07 strain than were the endemic SK fish. One caveat for this observation 
is that the modern SK fish tested here may be inherently different from the SK fish that were first exposed to a mG110M type virus, in 2002; modern SK fish likely contain some descendants of survivors of M group IHNV exposure. These results suggest some degree of heritable virus-resistance that is linked to surviving epidemic IHN disease.

Size-related resistance to mortality caused by the Qts07 was found to be a significant factor in only one fish population, although disease kinetics were slightly slower in older fish of both populations. Older LQ fish were more resistant than smaller fish to mortality caused by Qts07, but not to the degree of resistance in QN fish, at any age. This data is similar to results in rainbow trout, where resistance trended upward with fish age in a virus-strain dependent manner (LaPatra et al. 1990). It may be that increasing age is only protective in more vulnerable populations of steelhead trout; since only 2 of the 4 coastal steelhead trout populations in this report were examined for the role of age-related resistance, it is not clear whether age-related resistance might be a subtle co-factorial driver of heterogeneous impacts of IHNV. It is interesting that all coastal Washington cases of epidemic IHN disease associated with type mG110M virus occurred in a 2 mo window when all fish were of a similar age (Breyta et al. 2013). This implies that, at least during 2007-2009, differences in age-related resistance may not have been as strong a driver of IHNV mortality as variation in fish population susceptibility.

The differences in relative virulence between Qts07 and other IHNV strains were more subtle, only significant in 3 cases. For all M group strains tested, LQ fish suffered higher CPM than did the QN fish. In both LQ and QN fish, the Qts07 strain demonstrated virulence equivalent to the high-virulence reference 220-90 strain and also the Mer95 strain (Fig. 4E). However, the Qts07 strain was significantly more virulent than the LR80 strain in both LQ and QN fish. This indicates that in both of these coastal Washington fish populations there was no significant difference in virulence between 2 IHNV types that did emerge in the coastal region (mG111M and $\mathrm{mG} 110 \mathrm{M}$, represented by Mer95 and Qts07, respectively), but these types had significantly higher virulence than an IHNV type that did not emerge (mG007M, represented by LR80). Although preliminary, this result implies that inherent ability to kill infected fish may be linked to which $\mathrm{M}$ group IHNV viruses successfully emerged into coastal Washington steelhead trout. Still, it is not clear why type mG111M, which only caused one epidemic in coastal fish, would be similar in virulence to the type
mG110M, which emerged 10 yr later and caused many more epidemics. Since the experiments in this report use only a single virus strain to represent a virus genetic type, it may be that additional viral variation is not captured in this system. It is also likely that other parameters not tested here, such as ecological or anthropogenic factors, contribute to the overall emergence impact of a virus type. The IHNV types mG111M and $\mathrm{mG110M}$ have been reported to have similar replication fitness in co-infection and super-infection competition assays (Kell et al. 2014), but it may be that substantial differences exist between the 2 virus types in either host entry or virion shedding, as has been described with other types of IHNV (Peñaranda et al. 2009, Wargo \& Kurath 2011).

Taken together, the results described here indicate that several factors may be involved in creating a patchwork landscape of vulnerability to IHNV incidence and mortality. Since M group IHNV viruses were detected over a large geographic distribution during the course of a $5 \mathrm{yr}$ emergence event in coastal Washington, it seems clear that large differences in host susceptibility and more subtle differences in viral virulence, may be partly responsible for the heterogeneous burden observed.

Acknowledgements. Many thanks to partners in the Washington Dept. of Fish and Wildlife, the US Fish and Wildlife Service, the Northwest Indian Fisheries Commission, the Quinault Nation, and the Lower Elwha Klallam Tribe, for supplying virus field isolates and fish for controlled studies; to Paige Barlow for help with arcGIS map creation, and to Loveday Conquest for her statistical advice. This work was supported by the US Geological Survey, the US Fish and Wildlife Service, the Quinault Indian Nation, and Hatchery Reform Initiative NWIFC Contract No. 10HR E-1. Mention of trade names does not constitute endorsement by the US Government.

\section{LITERATURE CITED}

Amend DF, Nelson JR (1977) Variation in the susceptibility of sockeye salmon Oncorhynchus nerka to infectious hematopoietic necrosis virus. J Fish Biol 11:567-573

Anderson ED, Engelking HM, Emmenegger EJ, Kurath G (2000) Molecular epidemiology reveals emergence of a virulent infectious hematopoietic necrosis (IHN) virus strain in wild salmon and its transmission to hatchery fish. J Aquat Anim Health 12:85-99

Arkush KD, Mendonca HL, McBride AM, Hedrick RP (2004) Susceptibility of captive adult winter-run Chinook salmon Oncorhynchus tshawytscha to waterborne exposures with infectious hematopoietic necrosis virus (IHNV). Dis Aquat Org 59:211-216

Batts WN, Winton JR (1989) Enhanced detection of infectious hematopoetic necrosis virus and other fish viruses by pretreatment of cell monolayers with polyethylene glycol. J Aquat Anim Health 1:284-290 
Bergmann SM, Fichtner D, Skall HF, Schlotfeldt HJ, Olesen NJ (2003) Age- and weight-dependent susceptibility of rainbow trout Oncorhynchus mykiss to isolates of infectious haematopoietic necrosis virus (IHNV) of varying virulence. Dis Aquat Org 55:205-210

Bootland LM, Leong JC (1999) Infectious hematopoietic necrosis virus. In: Woo PTK, Bruno DW (eds) Fish diseases and disorders. CAB International, New York, NY, p 57-121

Bootland LM, Lorz HV, Drolet BS, Chen SJ, Fryer JL, Rohovec JS, Leong JC (1994) Current status of studies on the life cycle of infectious hematopoietic necrosis virus (IHNV). In: International Symposium on Aquatic Animal Health. University of California School of Veterinary Medicine, Davis, CA, p W-4.1

> Breyta R, Jones A, Stewart B, Brunson R and others (2013) Emergence of MD type infectious hematopoietic necrosis virus in Washington State coastal steelhead trout. Dis Aquat Org 104:179-195

Chen MF, Aikens CM, Fryer JL, Rohovec JS (1990) Virulence of four isolates of infectious hematopoietic necrosis virus in salmonid fishes and comparative replication in salmonid fish cell lines. Calif Fish Game 76:137-145

> Emmenegger EJ, Kurath G (2002) Genetic characterization of infectious hematopoietic necrosis virus of coastal salmonid stocks in Washington state. J Aquat Anim Health 14:25-34

Fijan N, Sulimanovic D, Bearzotti M, Muzinic D and others (1983) Some properties of the epithelioma papulosum cyprini (EPC) cell line from carp Cyprinus carpio. Ann Inst Pasteur Virol 134:207-220

> Garver KA, Troyer RM, Kurath G (2003) Two distinct phylogenetic clades of infectious hematopoietic necrosis virus overlap within the Columbia River basin. Dis Aquat Org 55:187-203

Garver K, Batts W, Kurath G (2006) Virulence comparisons of infectious hematopoietic necrosis virus $\mathrm{U}$ and $\mathrm{M}$ genogroups in sockeye salmon and rainbow trout. J Aquat Anim Health 18:232-243

Kell AM, Wargo AR, Kurath G (2014) Viral fitness does not correlate with three genotype displacement events involving infectious hematopoietic necrosis virus. Virology 464-465:146-155

Kurath G, Garver KA, Troyer RM, Emmenegger EJ, EinerJensen K, Anderson ED (2003) Phylogeography of infectious haematopoietic necrosis virus in North America. J Gen Virol 84:803-814

> LaPatra SE, Groberg WJ, Rohovec JS, Fryer JL (1990) Sizerelated susceptibility of salmonids to two strains of infectious hematopoietic necrosis virus. Trans Am Fish Soc 119:25-30

LaPatra SE, Lauda KA, Morton AW (1991) Antigenic and virulence comparisons of eight isolates of infectious hematopoietic necrosis virus from the Hagerman Valley, Idaho, USA. In: Anonymous Proceedings of the Second International Symposium on Viruses of Lower Vertebrates. Oregon State University, Corvallis, OR, p 125-132

LaPatra SE, Fryer JL, Rohovec JS (1993) Virulence comparison of different electropherotypes of infectious hematopoietic necrosis virus. Dis Aquat Org 16:115-120

> Mulcahy D, Bauersfeld K (1983) Effect of loading density of sockeye salmon, Oncorhynchus nerka (Walbaum), eggs in incubation boxes on mortality caused by infectious haematopoietic necrosis. J Fish Dis 6:189-193

Mulcahy D, Pascho R, Jenes CK (1983a) Mortality due to

Editorial responsibility: Mark Crane,

Geelong, Victoria, Australia infectious hematopoietic necrosis of sockeye salmon (Oncorhynchus nerka) fry in streamside egg incubation boxes. Can J Fish Aquat Sci 40:1511-1516

Mulcahy D, Pascho RJ, Jenes CK (1983b) Detection of infectious hematopoietic necrosis virus in river water and demonstration of waterborne transmission. J Fish Dis 6: 321-330

> Nichol ST, Rowe JE, Winton JR (1995) Molecular epizootiology and evolution of the glycoprotein and non-virion protein genes of infectious hematopoietic necrosis virus, a fish rhabdovirus. Virus Res 38:159-173

> Peñaranda MMD, Purcell MK, Kurath G (2009) Differential virulence mechanisms of infectious hematopoietic necrosis virus in rainbow trout (Oncorhynchus mykiss) include host entry and virus replication kinetics. J Gen Virol 90: 2172-2182

Purcell MK, Garver KA, Conway C, Elliott DG, Kurath G (2009) Infectious haematopoietic necrosis virus genogroup-specific virulence mechanisms in sockeye salmon, Oncorhynchus nerka (Walbaum), from Redfish Lake, Idaho. J Fish Dis 32:619-631

> Purcell MK, LaPatra SE, Woodson JC, Kurath G, Winton JR (2010) Early viral replication and induced or constitutive immunity in rainbow trout families with differential resistance to Infectious hematopoietic necrosis virus (IHNV). Fish Shellfish Immunol 28:98-105

Reed LJ, Muench H (1938) A simple method of estimating fifty per cent endpoints. Am J Hyg 27:493-497

Therneau TM, Grambsch PM (2000) Modeling survival data: extending the Cox model. Springer, New York, NY

Traxler GS, Roome JR, Kent ML (1993) Transmission of infectious hematopoietic necrosis virus in seawater. Dis Aquat Org 16:111-114

Troyer RM, Kurath G (2003) Molecular epidemiology of infectious hematopoietic necrosis virus reveals complex virus traffic and evolution within southern Idaho aquaculture. Dis Aquat Org 55:175-185

Venables WN, Ripley BD (2002) Modern applied statistics with S. Springer, New York, NY

- Wargo AR, Kurath G (2011) 2011) In vivo fitness associated with high virulence in a vertebrate virus is a complex trait regulated by host entry, replication, and shedding. J Virol 85:3959-3967

Wargo AR, Garver KA, Kurath G (2010) Virulence correlates with fitness in vivo for two M group genotypes of Infectious hematopoietic necrosis virus (IHNV). Virology 404:51-58

Wertheimer AC, Winton JR (1982) Differences in susceptibility among three stocks of chinook salmon, Oncorhynchus tshawytscha to two isolates of infectious hematopoietic necrosis virus. NOAA-TM-NMFS-F/NWC22

Wingfield WH, Fryer JL, Pilcher KS (1970a) Studies on the Sacramento River chinook disease and its causative agent. In: Snieszko SF (ed) A symposium on diseases of fish and shellfishes. American Fisheries Society, Bethesda, MD, p 307-318

Wingfield WH, Nims JL, Fryer JL, Pilcher KS (1970b) Species specificity of the sockeye salmon virus (Oregon strain) and its cytopathic effect in salmonid cell lines. In: Snieszko SF (ed) A symposium on diseases of fish and shellfishes. American Fisheries Society, Bethesda, MD, p 319-326

Wolf K (1988) Infectious hematopoietic necrosis virus. In: Anonymous Fish viruses and fish viral diseases. Cornell University Press, Ithaca, NY, p 83-114

Submitted: February 20, 2014; Accepted: June 16, 2014

Proofs received from author(s): November 10, 2014 